\title{
The origin of magnetic minerals in the Lake Khubsugul sediments (Mongolia)
}

\author{
D. K. Nourgaliev ${ }^{1}$, P. G. Iassonov $^{1}$, L. R. Kosareva ${ }^{1}$, A. Yu. Kazanskii ${ }^{2}$, and A. P. Fedotov ${ }^{3}$ \\ Received 7 March 2005; accepted 10 April 2005; published 21 April 2005.
}

[1] The aim of this paper is to discuss the results of studying the magnetic properties of sediments in the Khubsugul Lake (Mongolia). The samples of the sediments were collected at interval of $\sim 0.04 \mathrm{~m}$ from the cores of the hole drilled to a depth of $53 \mathrm{~m}$ in the central part of the lake. Magnetic hysteresis data were obtained for 1026 rock samples using a coercitive spectrometer. The most typical samples were used to derive thermomagnetic curves for induced magnetization. These measurements revealed high variations in the magnetic properties of the sediments, probably caused by drastic changes in the paleoclimate and tectonics. The samples were classified into two groups in terms of their magnetic values. The samples of the first group showed higher magnetic values, including their magnetic hardness, and those of the second group were found to be less magnetized and were classified as magnetically soft. In terms of their thermal magnetization curves the samples were found to contain magnetite, Ti magnetite, and magnetic iron sulfide (greigite). The magnetic data, as well as the substantial homogeneity of the magnetite in the first group of samples, prove that they contain biologically induced magnetite (BIM) and greigite (BIG). The samples of the second group contain mainly allothigenous magnetic grains, represented mainly by magnetite. The sources of these grains were the volcanic rocks surrounding the lake. The varying concentrations of the two types of the magnetic material in the samples suggest variations in the ratio of the allothigenous and authigenous materials in the sediments. The decline of the biogenic magnetic component in the sediments suggests the predomination of the allothigenous component caused by the growth of the erosion at the expense of monsoon or tectonic activity. The drastic changes in the contents of the biogenic magnetic component in the sediments suggest high variations in the sediment accumulation rate. This factor need be taken into consideration in the creation of a time scale for the sediments of this lake. INDEX TERMS: 1560 Geomagnetism and Paleomagnetism: Time variations: secular and longer; 3344 Atmospheric Processes: Paleoclimatology; 9320 Geographic Location: Asia; KEYWORDS: paleomagnetism, modern lake deposits, Khubsugul Lake.

Citation: Nourgaliev, D. K., P. G. Iassonov, L. R. Kosareva, A. Yu. Kazanskii, and A. P. Fedotov (2005), The origin of magnetic minerals in the Lake Khubsugul sediments (Mongolia), Russ. J. Earth. Sci., 7, ES3004, doi:10.2205/2005ES000173.

\section{Introduction}

[2] Lake sediments act as natural archives providing information for changes in the environment for the last $10^{4}$ to $10^{6}$ years in the annual to millennial scales [Evans and Heller, 2003]. The recent greatest project of studying the Baikal Lake sediments provided information for climate and tectonic activity variations for the period of more than 10 mil-

\footnotetext{
${ }^{1}$ Geological Faculty, Kazan State University, Kazan, Russia

${ }^{2}$ Institute of Geology, Siberian Division, Russian Academy of Science, Novosibirsk, Russia

${ }^{3}$ Limnological Institute, Siberian Division, Russian Academy of Science, Irkutsk, Russia
}

Copyright 2005 by the Russian Journal of Earth Sciences. ISSN: 1681-1208 (online) lion years [Kashiwaya et al., 2001; Prokopenko et al., 2002]. The low rate of sediment accumulation in large lakes does not allow one to get high-resolution records. Moreover, the existence of breaks and abrupt changes in the sediment accumulation rates preclude the creation of adequate time scales for the sedimentary rock cores. Variations in the deposition rate of the sediments are controlled not only by regional and global climatic and tectonic conditions but also by local factors, such as bottom water flows and turbidites.

[3] Proceeding from the study of the magnetic properties of sediments in the Khubsugul Lake, we determined the nature of the magnetic minerals of these sediments and proved the possibility of recording abrupt changes in the conditions and rate of sedimentation. The results of our study can be used to derive time scales for the sediment cores and to reconstruct environmental changes in the region for the last several million years. 


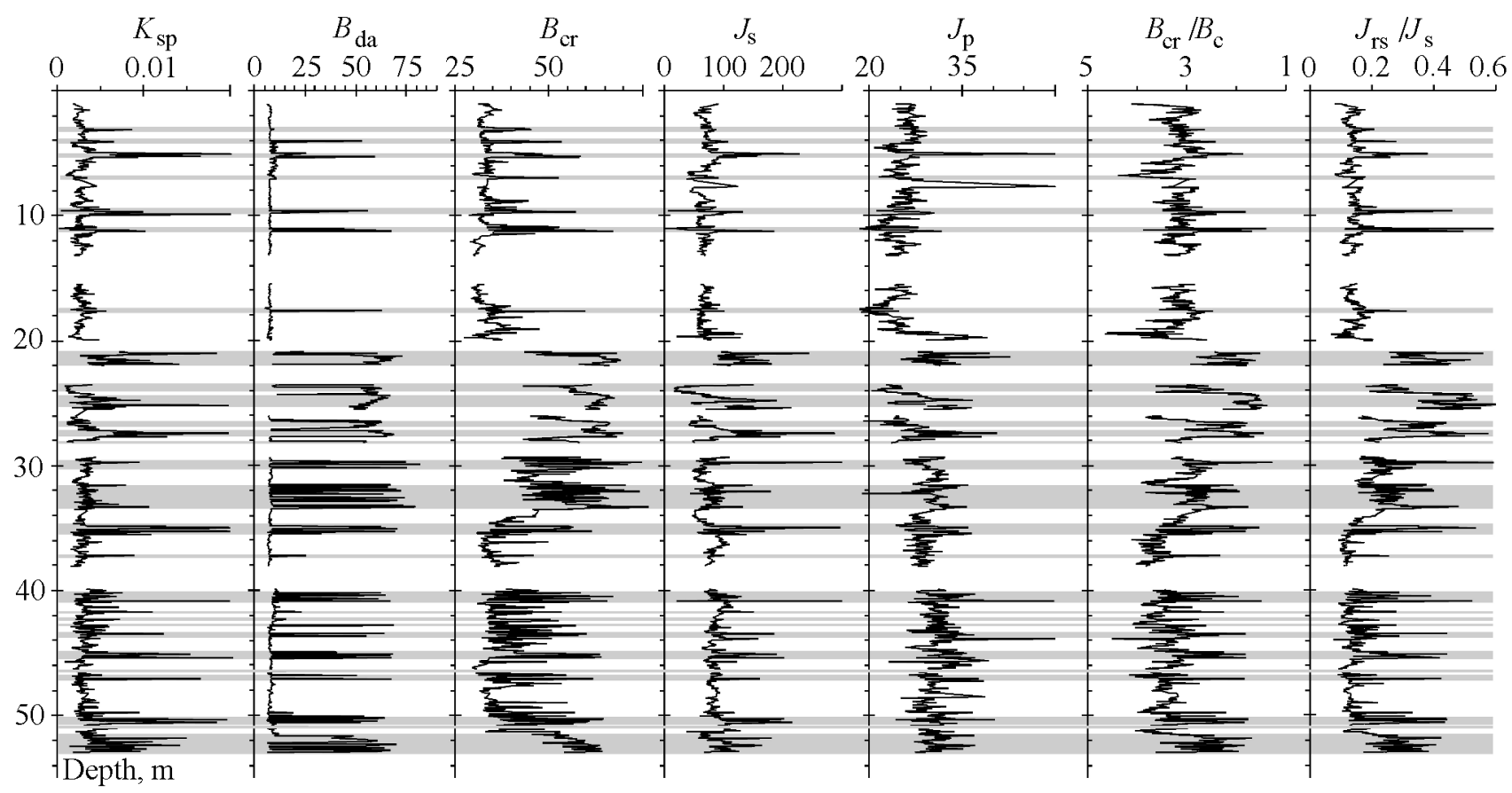

Figure 1. Variation of the magnetic parameters in the Khubsugul Lake sediments. The $B_{\text {cr }}$ and $B_{\text {da }}$ values are given in $\mathrm{mT}$; the $J_{\mathrm{s}}, J_{\mathrm{p}}$, and $K_{\mathrm{sp}}$ values are given in the same arbitrary units. The gray bands show the regions with highly magnetized sediments $\left(J_{\mathrm{s}}\right.$ and $K_{\mathrm{sp}}$ parameters $)$ and with the high magnetic rigidity of the magnetic material $\left(B_{\mathrm{cr}}\right.$ and $\left.B_{\mathrm{da}}\right)$ contained in the sediments.

\section{Brief Characteristics of the Objects of Our Study}

[4] Lake Khubsugul in North Mongolia occupies a depression in the Baikal Rift zone, the coordinates of its center being $51^{\circ} \mathrm{N}, 100^{\circ} 30^{\prime} \mathrm{E}, 1645$ asl. The mountains north and east of the lake reach an altitude of $2800-3400 \mathrm{~m}$ asl. It is the second largest lake (after Baikal Lake) in East Asia, which stores $383 \mathrm{~km}^{3}$ of water with its total water salinity of $180-200 \mathrm{mg} \mathrm{l}^{-1}$. Its maximum depth is $262 \mathrm{~m}$. The lake is $2760 \mathrm{~km}^{2}$ in area, its watershed area being $5130 \mathrm{~km}^{2}$. The outlet from the lake is the Egerin River flowing from its southernmost part. The mean atmospheric precipitation in the catchment area is $10-50 \mathrm{~mm}$ in winter and $300 \mathrm{~mm}$ in summer [Fedotov et al., 2004a, 2004b]. The bulk of this moisture is delivered from the North Atlantic area via Kazakhstan and Middle Asia [Kuznetsova, 1978]. The bottom sediments of Lake Khubsugul and of the other lakes of Mongolia have long since attracted a great interest of paleoclimatologists and were studied by Soviet-Mongolian expeditions at the end of the 20th century. It was found that many of the Mongolian lakes had been dry in the Pleistocene and were filled with water at the beginning of the Holocene. As to the Khubsugul Lake, a few sediment cores samples were collected and subject to qualitative analyses. It was reported [Altunbaev and Samarina, 1977] that the cores consisted of silt in their upper parts and of clay in the lower parts $[A l$ tunbaev and Samarina, 1977].
[5] Drilling was performed from ice by a team from the PBU Irkutskgeologiya Company (Russia) in the middle of the lake $\left(51^{\circ} 58^{\prime} 24^{\prime \prime} \mathrm{N}\right.$ and $100^{\circ} 24^{\prime} 33^{\prime \prime} \mathrm{E}$, at a depth of $232 \mathrm{~m}$. The high-frequency hydro-pulse drilling technique was able to raise undisturbed sediment cores ranging from $2 \mathrm{~m}$ to $6 \mathrm{~m}$ long. Most of the core samples consisted of silty clay with a minor admixture of sand and occasional gravels. The lower part of the lake sediments $(19-53 \mathrm{~m})$ was enriched in sand beds and lenses. The color of the sediments varied from gray to olive-gray, to olive-green, and to black. The total number of samples collected for magnetic and mineralogical studies was 1026 with a distance of $4 \mathrm{~cm}$ between them. The samples were dried in a refrigerator to protect them from oxidation and then subject to magnetic-mineralogical studies.

\section{Methods and Results of the Study}

[6] The isothermal remanent magnetization (IRM) of the rocks up to the values of $500 \mathrm{mT}$ was measured to study the carriers of remanent magnetization. Hysteresis and IRM curves were measured using a coercitivity spectrometer [Iassonov et al., 1998]. The high-field induced magnetization curves suggest the high concentrations of paramagnetic (PM) and superparamagnetic (SPM) materials and applied fields of nearly $150 \mathrm{mT}$ were necessary to attain higher than $95 \%$ of saturation IRM. This is typical of the magnetite or magnetic iron sulfides that usually occur in re- 
$J_{\mathrm{rs}} / J_{\mathrm{s}}$
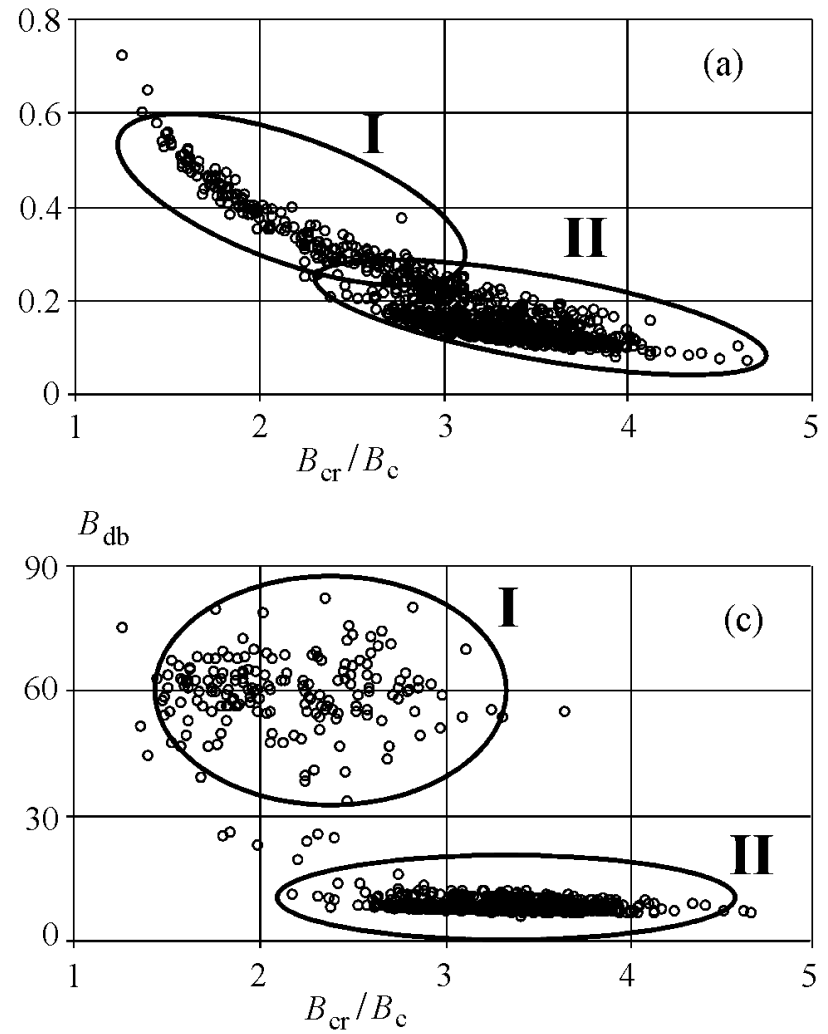

$J_{\mathrm{rs}} / J_{\mathrm{s}}$
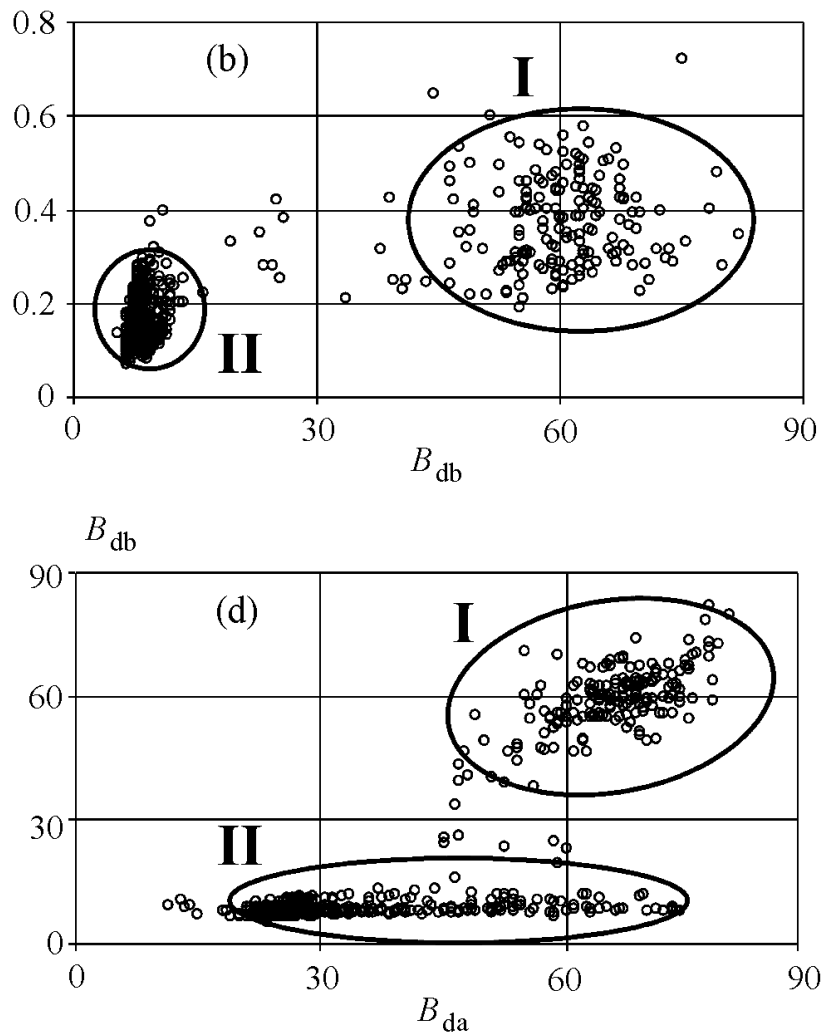

Figure 2. Relationships among the various magnetic parameters of the sedimentary rock samples collected in the Khubsugul Lake. (a) is a Day plot for the samples [Day et al., 1977]; (b) shows relationships for the $J_{\mathrm{rs}} / J_{\mathrm{s}}$ and $B_{\mathrm{db}}$ values; (c) a relationship between the $B_{\mathrm{cr}} / B_{\mathrm{c}}$ and $B_{\mathrm{db}}$ values; (d) a relationship between the $B_{\mathrm{da}}$ and $B_{\mathrm{db}}$ values. The samples of groups I and II are marked schematically in all Figures.

cent lake sediments [Snowball, 1994]. The small amounts of a high-coercitivity material might have been formed during the recovery of samples as a result of the very fast oxidation of iron in the sulfides and in other minerals containing ferrous iron.

[7] The following parameters were measured using the IRM curves: normal remanent saturation magnetization $\left(J_{\mathrm{rs}}\right)$, saturation magnetization, excluding the effect of the paramagnetic component $\left(J_{\mathrm{s}}\right)$, the magnetization of the paramagnetic component in the field of $0.5 \mathrm{~T}\left(J_{\mathrm{p}}\right)$, the coercivity force after removing the effect of the paramagnetic component $\left(B_{\mathrm{c}}\right)$, the remanent coercitivity force $\left(B_{\mathrm{cr}}\right)$, the position of the $d J_{\mathrm{r}} / d B_{\mathrm{a}}$ derivative peak value (normal magnetization along the $a$ axis of the Preizah-Neel diagram $\left(B_{\mathrm{da}}\right)$, the position of the $d J_{\mathrm{r}} / d B_{\mathrm{b}}$ derivative peak value (normal remagnetization along the $b$ axis of the Preizah-Neel diagram $\left(B_{\mathrm{db}}\right)$, and a superparamagnetic susceptibility in the field of up to $8 \mathrm{mT}\left(K_{\mathrm{sp}}\right)$.

[8] The variations of these magnetic values (Figure 1) show drastic changes in the properties of the magnetic mineral grains contained in the sediments. The section areas marked by gray bands in Figure 1 are distinguished by the high magnetization of the sediments (in terms of $J_{\mathrm{s}}$ and $K_{\mathrm{sp}}$ values) and by the high magnetic rigidity of the magnetic material $\left(B_{\mathrm{cr}}, B_{\mathrm{da}}\right)$ contained in the sediments. This figure also shows some ratios between these parameters. For in- stance, the $B_{\mathrm{cr}} / B_{\mathrm{c}}$ and $J_{\mathrm{rs}} / J_{\mathrm{s}}$ values provide information for the domain structure of the ferrimagnetic materials contained in the sediments [Day et al., 1977]. The relationships among some of the magnetic parameters of the Khubsugul Lake sediments are shown more clearly in Figure 2. One can see that in terms of their magnetic properties the sediments can be subdivided into two groups (Figure 2). This is most clearly seen in terms of the relationship between the $B_{\mathrm{db}}$ and $B_{\text {da }}$ parameters (Figure 2d). Table 1 lists the average values of some magnetic parameters for the samples of both groups (Figure 2).

[9] The $B_{\mathrm{db}}$ and $B_{\mathrm{da}}$ values are similar for the samples of group I, and differ for the samples of group II. The use of a Preisach diagram [Dunlop and Özdemir, 2001] allows one to estimate the extent of magnetic interaction in ferrimagnetic grain ensembles. In our case this suggests the presence of a high magnetostatic interaction between the magnetic grains of the group II samples and of the almost complete absence of interaction between the magnetic grains in the group I sediments. It can be supposed that the magnetic material in the group I sediments is represented by single-domain (SD) grains, and that of the group II sediments, by multidomain (MD) grains. This is also proved by their $B_{\mathrm{cr}} / B_{\mathrm{c}}$ and $J_{\mathrm{rs}} / J_{\mathrm{s}}$ values (Table 1 ). The theoretical values reported in the literature [Dunlop and $\ddot{O} z$ demir, 2001] for the assemblages of SD grains are $\sim 1.5$ for $B_{\text {cr }} / B_{\mathrm{c}}$ and $\sim 0.5$ for $J_{\mathrm{rs}} / J_{\mathrm{s}}[D u n-$ 
Table 1. Average values of the magnetic parameters for samples of I and II groups

\begin{tabular}{lcc}
\hline Magnetic parameters & I group & II group \\
\hline$B_{\mathrm{da}}$ & $65.9 \pm 7.45$ & $29.8 \pm 9.7$ \\
$B_{\mathrm{db}}$ & $59.65 \pm 8.18$ & $8.27 \pm 1.87$ \\
$B_{\mathrm{cr}} / B_{\mathrm{c}}$ & $2.15 \pm 0.45$ & $3.27 \pm 0.37$ \\
$J_{\mathrm{rs}} / J_{\mathrm{s}}$ & $0.37 \pm 0.1$ & $0.15 \pm 0.05$ \\
\hline
\end{tabular}

lop and Özdemir, 2001], yet our samples of group I showed these values to be $\sim 2.15 \pm 0.45$ and $\sim 0.37 \pm 0.1$, respectively, see Table 1. This seems to be associated with the fact that these samples contained a mixture of SD and MD grains and also superparamagnetic grains [Dunlop, 2002], which is proved by the high $K_{\mathrm{sp}}$ values (Figure 1 ). The samples of group II contain mostly MD grains, which is proved by the values of all parameters presented in Table 1. It can, thus, be supposed that a great difference of the magnetic hysteresis properties of the group I and II samples is caused by the different sizes of the magnetic grains. The coercitivity spectra of the most typical samples of groups I and II are presented in Figure 3. The peaks of these spectra plotted for the above-mentioned samples of groups I and II amount to $84 \mathrm{mT}$ and $48 \mathrm{mT}$, respectively (Figure 3 ).

[10] The magnetizations induced in a field of $200 \mathrm{mT}$ (IM) and measured as a function of temperature provided further evidence for the magnetic minerals. These curves were obtained during the continuous heating of small samples ( $\sim 30 \mathrm{cu} . \mathrm{mm}$ in size $)$ at a rate of $100^{\circ} \mathrm{C} \mathrm{m^{-1 }}$ using homebuilt sensitive instruments [Burov et al., 1986]. The high heating rate is supposed to prohibit oxidation of the smallest particles of magnetic minerals and to allow the recognizing for instance the Curie temperatures of the very small particles of magnetic iron sulfides, which would have been obstructed at lower heating rates.

[11] The typical curves of the two successive heatings of two samples are plotted in Figure 4. The mineral phases with the Curie temperatures of $560-580^{\circ} \mathrm{C}$ can represent magnetite ( $\mathrm{a}$ and $\mathrm{b}$ in Figure 4). The faint features in the first

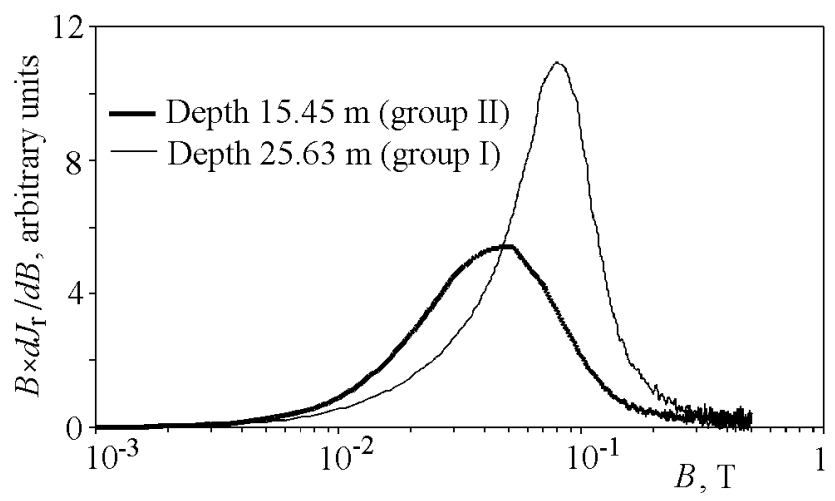

Figure 3. Coercivity spectra for the typical samples of groups I and II.

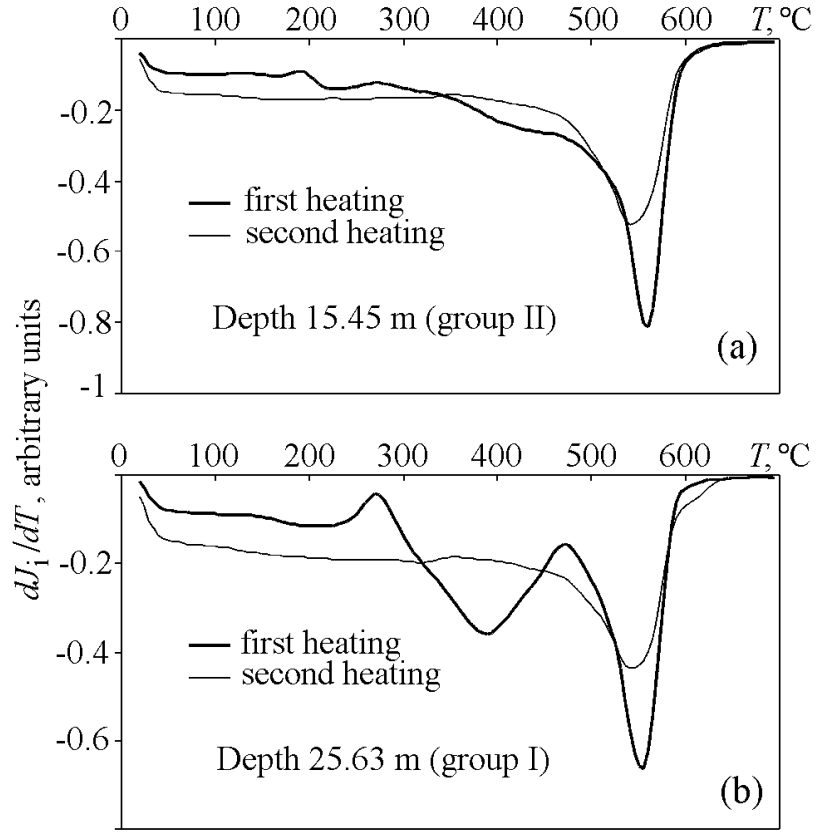

Figure 4. The curves of the differential analyses of the typical samples of groups II (a) and I (b). Also shown in this figure are the differential curves for the first and second heating of the samples.

heating cycle around $250-300^{\circ} \mathrm{C}$ (Figure $4 \mathrm{~b}$ ) may suggest the presence of iron sulfide (most probably greigite) which disappeared in the second run having been destroyed apparently [Burov et al., 1986]. The magnetic minerals may have originated in different ways: derived from the catchment soil erosion and aerial regional (or even global) allogenic input, the biogenic formation of magnetite and/or greigite [Bazylinski and Moskowitz, 1997] and the dissolution of iron oxides and the growth of secondary iron sulfides such as pyrite or greigite [Tarduno, 1995], or the formation of new authigenic magnetic mineral phases including magnetite [Karlin et al., 1987]. Variations of the magnetic properties of the core samples provide information concerning the potential effects of these processes on the formation of a magnetic fraction in these lacustrine sediments (Figure 1).

\section{Discussion of the Results and Conclusions}

[12] As a first approximation, the magnetic signal of the Khubsugul Lake owes its origin to the presence of the following two types of magnetic material fractions and their mixtures:

[13] - the group I sediments contain predominantly SD ferrimagnetic grains composed of magnetite and magnetic iron sulfide, the coercivity of the ferromagnetic component $\left(B_{\mathrm{cr}}\right)$ being $61.9 \pm 5.8 \mathrm{mT}$;

[14] - the group II sediments contain predominantly MD 
ferrimagnetic grains composed of magnetite, the magnetization $\left(J_{\mathrm{rs}}\right)$ of these sediments is $4-5$ times lower than that of the group I sediments, the coercitivity of the ferrimagnetic component $\left(B_{\mathrm{cr}}\right)$ being $38.1 \pm 7.7 \mathrm{mT}$ which is substantially lower than the of the group I sediments.

[15] The data obtained in this study suggest some assumptions concerning the origin of these magnetic rock fractions and use their concentration variations for reconstructing changes in the environment. We believe that the magnetic fraction of the group I rock samples is represented by single-domain grains of biogenic origin. In the first place, this is suggested by the very narrow range of the $B_{\mathrm{cr}}$ values and by the peaks of the coercive spectra of the samples (Figure 3), in the second place, the allothigenic ferrimagnetic fraction cannot be so well "sorted": it must contain large (multidomain) grains, and in the third place, the same samples may contain single-domain grains of magnetite and magnetic iron sulfide (Figure 4) only in the case of their authigenic (biogenic) origin. It is known that the same "magnetotactic" bacteria can produce magnetite or grayite (magnetic iron sulfide) [Bazylinski and Moskowitz, 1997]. Besides, it is necessary to mention, that the maximum of a coercitive spectrum in the first group of samples, equals the number, fixed earlier for bacterial magnetite and greigite [Egli, 2004; Moskowitz et al., 1993; Snowball, 1994; Snowball et al., 2002]. The magnetic material, dominating in the rock samples of Type II seems to be represented by allothigenic magnetite grains, often oxidized in the course of their transportation, as indicated by a low magnetization decline in the temperature range of $350-450^{\circ} \mathrm{C}$ in the first-heating curves (Figure 4a), usually associated with the transition of magnetite to hematite [Burov et al., 1986].

[16] This rock sequence can be subdivided into two segments in terms of changes in the magnetic properties of the sediments. The upper sedimentary rocks extending to a depth of $19.8 \mathrm{~m}$ differ from the underlying rocks in terms of their total magnetization, coercitivity, and magnetic property variation, as well as in the values and behavior of their paramagnetic magnetization $\left(J_{\mathrm{p}}\right)$. The variation of the $J_{\mathrm{p}}$ trends and average values of the sediments could be caused by changes in the relative contents of clay minerals in the sediment. This fact can also be used for estimating the content of the terrigenous component in the sediments, this component reflecting the intensity of the removal of the rock material to the sediment accumulation basin under the effects of tectonic and climatic factors. Below the depth of $19.8 \mathrm{~m}$ the $J_{\mathrm{p}}$ value is averagely higher than in the overlying rocks. The rocks residing above this depth level show a stable growth (trend) of the $J_{\mathrm{p}}$ value. This variation trend in of the paramagnetic component content in the sediments might have been associated with tectonic factors. The $J_{\mathrm{p}}$ peaks at the depth of about $20 \mathrm{~m}$ seem to have been caused by tectonic events. For example, the variation trends of the $B_{\mathrm{cr}} / B_{\mathrm{c}}$ and $J_{\mathrm{rs}} / J_{\mathrm{s}}$ parameters, as well as the decline of the $J_{\mathrm{p}}$ value from the depth of $\sim 36 \mathrm{~m}$ to $\sim 25 \mathrm{~m}$, suggest a decline in the addition of the allothigenic component to the sedimentation basin.

[17] The most important result of this study is the discovery of an abrupt change in the ratio of the allogenic and authigenic (biogenic) material in the Khubsugul Lake sedi- ments, this proving the complex sedimentation pattern with numerous breaks and abrupt changes in the rate of sedimentation. This is most distantly recorded in the spasmodic $B_{\text {da }}$ parameter variations (Figure 1 and Figure 2d), associated with an abrupt change in the ferrimagnetic fraction of the sediments (a ratio between the biogenic and terrigenous components). The relative concentration of biogenic materials in the sediments seems to be controlled by the following main factors:

[18] (1) The rate of allothigenic material supply to the sedimentation basin. The higher the content of the allothigenic material in the sediment, the naturally lower the content of its biogenic material. Variations of this factor may be caused both by tectonic and climatic factors.

[19] (2) The biologic productivity of the water and sediments, which is controlled, in its turn, by the lake's trophic state index [Wetzel, 2001]. This controls the position of the boundary between the oxidation and reduction zones in the water and in the sediments. For instance, magnetotactic bacteria are most productive where this boundary resides in water rather than in the sediments [Bazylinski and Moskowitz, 1997]. This is possible only where the lake's trophic state index is sufficiently high. Changes in this factor can be caused mainly by climatic factors.

[20] It is natural that these factors produce a combined effect on the formation of the sediment properties. The type of their interaction is controlled by the type of the lake water supply and by the morphology and profile of the basin.

[21] Therefore, it is most likely that the rate of sediment accumulation in this basin with the large amount of a biogenic magnetic material is substantially lower than that of the sediments predominated by the terrigenous material. The paleoclimatic interpretation of the data available can be performed using the results of the paleobiological (paleontological) data available. At the present time it can only be mentioned that a decline in the addition of a terrigenous material into the Khubsugul Lake basin might have taken place during a decline in the general humidity and during the lake level decline, but under the conserved conditions of sufficiently high bioproductivity. On the other hand, the diminished addition of a terrigenous material might have been caused by the long periods of time when the lake was covered by ice, which were followed by the periods of ice thawing and the abrupt growth of the allogenic material added to the lake.

[22] Acknowledgment. This study was supported by the Russian Foundation for Basic Research, Project no. 04-05-64543-a.

\section{References}

Altunbaev, V. H., and A. V. Samarina (1977), Characteristics of the Khubsugul Lake bottom sediments, in The Natural Conditions and Mineral Resources of the Khubsugul Region in Mongolia, Proc. Soviet-Mongolian Khubsugul Expedition, rm vol. 5 (in Russian), p. 80, Irkutsk Univ. Press, Irkutsk.

Bazylinski, D. A., and B. M. Moskowitz (1997), Microbial Biomineralization of Magnetic Iron Minerals: Microbiology, 
Magnetism and Environmental Significance, Mineral. Society of America Reviews in Mineralogy, 35, 181.

Burov, B. V., D. K. Nourgaliev, and P. G. Iassonov (1986), Paleomagnetic Analysis (in Russian), 176 pp., Kazan Univ. Press, Kazan.

Day, R., M. Fuller, and V. Schmidt (1977), Hysteresis properties of titanomagnetites: Grain-size and composition dependence, Phys. Earth Planet. Inter., 13, 260.

Dunlop, D. (2002), Theory and application of the Day plot $\left(M_{\mathrm{rs}} / M_{\mathrm{S}}\right.$ versus $\left.H_{\mathrm{cr}} / H_{\mathrm{c}}\right):$. Theoretical curves and tests using titanomagnetite data, J. Geophys. Res., 107, 260, doi:doi:10.1029/2001JB000486.

Dunlop, D., and O. Ozdemir (2001), Rock Magnetism: Fundamentals and Frontiers, 573 pp., Cambridge Univ. Press, Cambridge.

Egli, R. (2004), Characterization of individual rock magnetic components by analyzing remanence curves, 3. Bacterial magnetite and natural processes in lakes, Phys. Chem. Earth, Part A, Part B and Part C, 29(13-14), 869.

Evans, M., and F. Heller (2003), Environmental Magnetism, Principles and Applications of Enviromagnetics, 299 pp., Academic Press, San Diego.

Fedotov, A., A. Kazansky, and Tomurhuu Dondovyn (2004a), A 1-Mil.yr. record of paleoclimates from Lake Khubsubul, Mongolia, Eos, 85, 387.

Fedotov, A., E. Chebykin, and M. Semenov (2004b), Changes in the volume and salinity of Lake Khubsugul, Mongolia, in response to global climate changes in the Upper Pliocene and the Holocene, Paleogeogr. Palaeoclimatol. Palaeoecol., 209(14), 245 .

Iassonov, P. G., D. K. Nourgaliev, B. V. Burov, and F. Heller (1998), A modernized coercivity spectrometer, Geologica Carpathica, 49, 224.

Karlin, R., M. Lyle, and G. R. Heath (1987), Authigenic magnetite formation in suboxic marine sediments, Nature, 326, 490.
Kashiwaya, K. M., Sh. Ochiai, H. Sakai, and T. Kawai (2001), Orbit-related long-term climate cycles revealed in a 12-Ma continental record from Lake Baikal, Nature, 410, 71.

Kuznetsova, L. P. (1978), Transfer of Moisture over the Territory of the USSR (in Russian), 21 pp., Nauka, Moscow.

Moskowitz, B., B. Richard, R. Frankel, and D. Bazylinski (1993), Rock magnetic criteria for the detection of biogenic magnetite, Earth Planet. Sci. Lett., 120(3-4), 283.

Prokopenko, A., D. Williams, and M. Kuzmin (2002), Muted climate variations in continental Siberia during the MidPleistocene Epoch, Nature, 418, 65.

Snowball, I. (1994), Bacterial magnetite and the magnetic properties of sediments in a Swedish lake, Earth Planet. Sci. Lett., $126(1-3), 129$

Snowball, I., L. Zillen, and P. Sandgren (2002), Bacterial magnetite in Swedish varved lake sediments: A potential biomarker of an environmental change, Quaternary International, 88(1), 13.

Tarduno, J. A. (1995), Superparamagnetism and reduction diagenesis in pelagic sediments: enhancement or depletion?, Geophys. Res. Lett., 22, 1337.

Wetzel, R. G. (2001), Limnology, Lake and River Ecosystems, 1006 pp., Academic Press, St. Louis, MO.

A. P. Fedotov, Limnological Institute, Siberian Division, Russian Academy of Science, 3 Ulan-Bator Str., Irkutsk, 644033 Russia

P. G. Iassonov, L. R. Kosareva, D. K. Nourgaliev, Geological Faculty, Kazan State University, 18 Kremlevskaya ul., Kazan, 420008, e-mail: danis.nourgaliev@ksu.ru

A. Yu. Kazanskii, Institute of Geology, Siberian Division, Russian Academy of Science, 3 Akademik Koptyug Prospect, Novosibirsk, 630090 Russia 